岩石銥物銥床学会誌

63 巻 1 号, 1970 年

\title{
MORDENITE IN RHYOLITE AT YOSHIDA AREA, KAGOSHIMA PREFECTURE
}

\author{
Katsutoshi Tomita, Hiroyuki Yamashita and Noboru ŌBa \\ Institute of Earth Sciences, Faculty of Science, Kagoshima University
}

\begin{abstract}
A fibrous mordenite was found in cavities in a rhyolite. The mordenite was formed probably by a result of hydrothermal mineralization.
\end{abstract}

\section{INTRODUCTION}

Mordenite is found in an authigenic mineral in sediments (Hayashi and Sudo, 1957). Mordenite occurs in vesicular andesite, basalt and dolerite vesicles. Some mineralogical data of a mordenite found in a rhyolitic rock are described in this paper.

\section{OCGURRENGE}

Andesite is widely distributed in Yoshida area, Kagoshima Prefecture, and some small lenticular blocks of rhyolite are placed on the andesite. The rhyolite rock has been regarded as the product of the Pliocene intrusion. The rhyolite rock is covered by welded tuff which is distributed widely in this area. The welded tuff is regarded to be the deposits accumulated during the period of transgression ranging from the Pliocene to the Pleistocene. Pleistocene deposits of pumice flow (so-called Shirasu) were successively occurred on the welded tuff. The mordenite is found as finely fibrous or cottony material in vesicles in rhyolite. The mineral is white with a pink tint and its length is about $3 \mathrm{~mm}$. The host rock is reddish rhyolite. A chemical analysis of the rhyolite shows a lower silica content than average rhyolite composition.

\section{MINERALOGICAL DATA}

The sample which was pulverized in an agate mortar was examined by means of X-ray, thermal, infrared absorption and chemical analyses. $X-r a y$ analysis

$\mathrm{X}$-ray powder pattern of the mordenite was taken employing an X-ray

Manuscript received, September 29, 1969 
diffractometer (CuKa, $\mathrm{Ni}$ filter). The mineral is well crystallized and gives many measureable peaks. Table 1 compares the powder data for the mordenite and a natural mordenite examined by Harris and Brindley (1954). The powder data have been indexed for the lower order reflections and the orthorhombic cell dimensions derived therefrom are given in Table 2 where they are compared with those given by Harris and Brindley. There was little difference between the diffraction pattern of the original

Table 1. X-ray powder data for mordenite $\left(\mathrm{CuK}_{\mathbf{a}}=1.5418 \mathrm{~A}\right)$

\begin{tabular}{|c|c|c|c|c|c|}
\hline \multirow[b]{2}{*}{ hkl } & \multicolumn{3}{|c|}{1} & \multicolumn{2}{|c|}{2} \\
\hline & dobs. $(\AA)$ & I & $\mathrm{d}_{\mathrm{calc}} \cdot(\AA)$ & $\mathrm{d}_{\text {obs. }}(\mathrm{A})$ & I \\
\hline 110 & 13.7 & 20 & 13. 6 & 13.7 & 6 \\
\hline 200 & 9.12 & 43 & 9.12 & 9. 10 & 9 \\
\hline 111 & 6.60 & 7 & 6.59 & 6.60 & 8 \\
\hline 130 & 6.41 & 60 & 6.36 & 6.39 & 5 \\
\hline 021 & 6.09 & 2 & 6.06 & 6.09 & 2 \\
\hline 201 & 5.82 & 20 & 5.81 & 5.80 & 5 \\
\hline 221 & - & - & - & - & - \\
\hline 131 & - & - & - & 一 & - \\
\hline 330 & 4.529 & 44 & 4.528 & 4. 535 & 8 \\
\hline 420 & 4. 152 & 10 & 4. 160 & - & 一 \\
\hline 150 & 3.990 & 100 & 3.975 & 4. 008 & 9 \\
\hline 241 & 3.840 & 7 & 3.830 & 3.854 & 4 \\
\hline 002 & 3.770 & 4 & 3.770 & 3.778 & 4 \\
\hline 112 & 3.640 & 3 & 3.632 & - & 一 \\
\hline 510 & 3.576 & 4 & 3.590 & - & - \\
\hline 202 & 3. 480 & 20 & 3. 483 & 3. 486 & 10 \\
\hline 060 & 3. 394 & 64 & 3. 394 & 3.398 & 9 \\
\hline 222 & 3. 290 & 2 & 3. 295 & 3.315 & 1 \\
\hline 530 & 3. 209 & 40 & 3.213 & 3.224 & 9 \\
\hline 441 & 3.100 & 3 & 3.096 & - & - \\
\hline 531 & 2.950 & 4 & 2.955 & - & - \\
\hline 402 & 2.903 & 40 & 2.905 & 2.899 & 7 \\
\hline 152 & 2.740 & 2 & 2.735 & 2.746 & 1 \\
\hline 621 & 2.706 & 6 & 2.717 & 2.706 & 1 \\
\hline 370 & 2.636 & 4 & 2.623 & - & - \\
\hline 461 & 2.560 & 15 & 2.560 & 2.569 & 3 \\
\hline 422 & 2.522 & 7 & 2. 522 & 2.534 & 5 \\
\hline
\end{tabular}

1. Mordenite in rhyolite.

2. Natural mordenite, examined by Harris and Brindley (1954). 
Table 2. Unit cell dimensions of mordenite

\begin{tabular}{c|c|c}
\hline & 1 & 2 \\
\hline $\mathrm{a}$ & $18.16 \pm 0.10 \AA$ & $18.24 \pm 0.10 \AA$ \\
$\mathrm{b}$ & $20.45 \pm 0.10$ & $20.36 \pm 0.05$ \\
$\mathrm{c}$ & $7.54 \pm 0.05$ & $7.54 \pm 0.05$ \\
\hline
\end{tabular}

1. Data by Harris and Brindley (1954).

2. Present data.

specimen and the one heated at $950^{\circ} \mathrm{C}$ for one hour except the slight changes of the very faint diffraction lines. This result shows little or no change in the crystal structure after heating at $950^{\circ} \mathrm{C}$.

\section{Chemical analysis}

Chemical analysis of the mordenite purified by hand picking was made by the ordinary wet method. The result is compared in Table 3 with the rhyolite host rock. The analysis of the mordenite fraction may be recalculated in conformity with the theoretical mordenite structure (Ca, $\left.\mathrm{Na}_{2}, \quad \mathrm{~K}_{2}\right)_{2} \mathrm{Al}_{4} \mathrm{Si}_{20} \mathrm{O}_{48} 14 \mathrm{H}_{2} \mathrm{O}$. The analysis gives a formula $\left(\mathrm{Mg}_{0.25} \mathrm{Mn}_{\mathbf{0 . 0 4}}\right.$ $\left.\mathrm{Ca}_{0.94} \mathrm{Na}_{1.06} \mathrm{~K}_{0.49}\right) \quad\left(\mathrm{Al}_{4.14} \quad \mathrm{Fe}_{0.28}\right) \quad\left(\mathrm{Si}_{19.65} \quad \mathrm{Ti}_{0.04}\right) \quad 0_{48} 13.32 \mathrm{H}_{2} \mathrm{O}$, which is reasonably close to the host rock. The analyses show that the main changes are small removals of alkalis and a considerable increase of water content. Total $(\mathrm{Si}+\mathrm{Al})$ is close to the theoretical value of 24 . Potassium

Table 3. Chemical analyses of rhyolite and mordenite

\begin{tabular}{l|c|c} 
& 1 & 2 \\
\hline $\mathrm{SiO}_{2}$ & $65.68 \%$ & $66.32 \%$ \\
$\mathrm{TiO}_{2}$ & 0.64 & 0.20 \\
$\mathrm{Al}_{2} \mathrm{O}_{3}$ & 15.33 & 11.85 \\
$\mathrm{Fe}_{2} \mathrm{O}_{3}$ & 3.80 & 1.23 \\
$\mathrm{FeO}$ & & \\
$\mathrm{MnO}$ & 0.23 & 0.15 \\
$\mathrm{MgO}$ & 0.35 & 0.57 \\
$\mathrm{CaO}$ & 3.74 & 2.97 \\
$\mathrm{Na}_{2} \mathrm{O}$ & 3.70 & 1.84 \\
$\mathrm{~K}_{2} \mathrm{O}$ & 1.34 & 1.30 \\
$\mathrm{H}_{2} \mathrm{O}(+)$ & 2.62 & 8.71 \\
$\mathrm{H}_{2} \mathrm{O}(-)$ & 2.46 & 4.78 \\
$\mathrm{P}_{2} \mathrm{O}_{5}$ & 0.02 & 0.01 \\
\hline $\mathrm{Total}$ & $99.91 \%$ & 99.9396 \\
\hline
\end{tabular}

(1) Rhyolite, (2) Mordenite, 
is less abundent than sodium. Iron is moro abundant than normal mordenites. Harris and Brindley (1954) reported that material occurring as the hydration product of pitchstone glass has been shown to have 1.74 per cent. $\mathrm{Fe}_{2} \mathrm{O}_{3}$. The pinkish color of the mordenite is possibly related to the content of $\mathrm{Fe}_{2} \mathrm{O}_{3}, 1.23 \%$.

\section{Differential thermal analysis}

Differential thermal analysis curve which is shown in Fig. 1 was taken with an automatic thermal analyser at a heating rate of $10^{\circ} \mathrm{C}$ per minute for the mordenite. The differential thermal analysis curve shows low endothermic reaction due to dehydration. A broad endothermic peak between $100^{\circ} \mathrm{C}$ and $200^{\circ} \mathrm{C}$ was identical to that of previous worker (Koizumi, 1953).

\section{Infrared absorption analysis}

The infrared absorption curve of the mordenite was obtained with a Shimadzu IR-6 type infrared absorption recording spectrometer using Nujol paste method. The infrared absorption spectrum of the mordenite shown in Fig. 2 is characterized by the presence of absorption bands with peaks at 3640,3450 and $1640 \mathrm{~cm}^{-1}$. The bands of absorption around $3450 \mathrm{~cm}^{-1}$ are probably due to adsorbed water as indicated by comparison with montmorillonite data of Wolff (1965). The absorption bands at $3450 \mathrm{~cm}^{-1}$ in the water-stretching region are spread toward higher frequencies. This phenomenon has also been described in stilbite by Harada and Tomita (1967). Some amounts of water in these zeolite minerals are considered to be structurally bound. The absorption bands around $3600 \mathrm{~cm}^{-1}$ may be attributed to structurally bound water. A clear asymmetrical absorption at $1640 \mathrm{~cm}^{-1}$ due to adsorbed water is visible.

\section{GONCLUSION}

The chemical and $\mathrm{X}$-ray data combine to show that the hydrothermal product is the zeolite mordenite. The close similarity in chemical com-

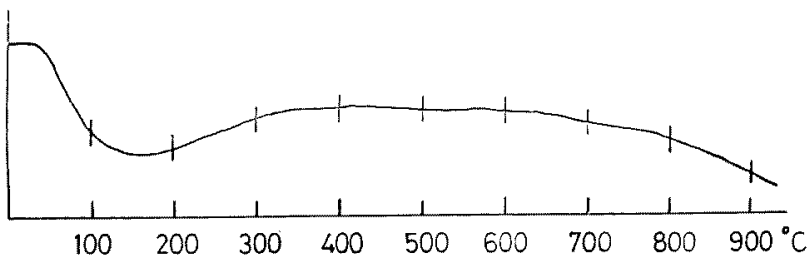

Fig. 1. Differential thermal analysis curve of mordenite, 


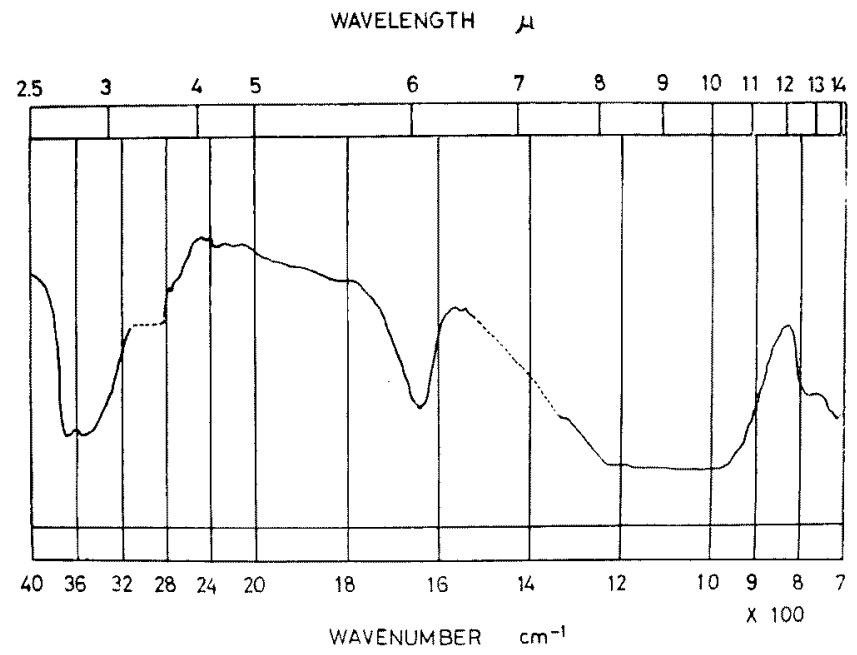

Fig. 2. Infrared absorption curve of mordenite.

position of the original rock and the resultant zeolite suggests that the nature of the zeolites formed from rock by its hydration, depends largely on the composition of the original material.

\section{ACKNOWLEDGEMENTS}

The writers wish to sincere thanks to Professors T. Hase and M. Nakatani of the Chemical Institute of Kagoshima University, who provided convenience for the use of infrared spectrometer. Deep gratitude is also expressed to all staffs of the Institute of Earth Sceinces, Kagoshima University, for their valuable comments on this study. The present study has been supported by a Grant in Aid for Scientific Research from the Ministry of Education.

\section{REFENCES}

Harada, K. and Tomita, K. (1967), Sodian stilbite from Onigajo, Mie Prefecture, Japan, with some experimental studies concerning the conversion of stilbite to wairakite at low water vapor pressures. Amer. Miner., 52, 1438 1450.

Harris, P.G. and Brindley, G.W. (1954), Mordenite as an alteration product of a pitchstone glass. Amer. Miner., 39, $819 \sim 824$.

Hayashi, $H$. and Sudo, T. (1957), Zeolite-bearing bentonites. Miner. Jour. (Japan), 2, 196 199 .

Koizumi, M. (1953), The differential thermal analysis curves and the 
dehydration curves of zeolites. Miner. Jour. (Japan), 1, $36 \sim 47$.

Wolf, R.G. (1965), Infrared absorption patterns (OH region) of several clay minerals. Amer. Miner., 50, $240 \sim 244$.

\title{
鹿児島県吉田地域の流紋岩中のモルデン沸石
}

\author{
富田克利山山下広幸・大庭䒜
}

摘 要

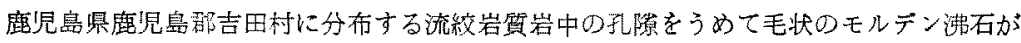
晶出しているのを胃いだした。わが国では，モルデン扸石か酸性岩䝷岩石中より見いださ れるのは珍しいがこの沸石の化学分析值は原岩の流䜌岩石のそれとよく一致しており，火

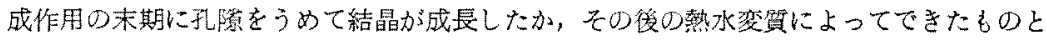
思われる。 